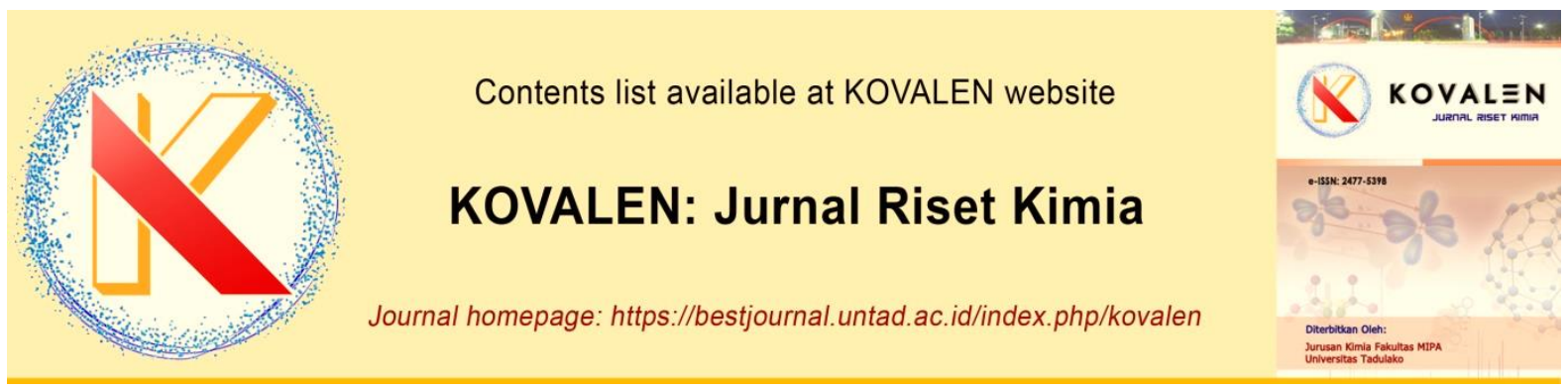

\title{
Analisis Kadar Vitamin C Bawang Putih dan Hitam dengan Metode Spektrofotometri UV-Vis
}

\author{
[Analysis of Vitamin C Levels of Garlic and Black Garlic by UV-Vis \\ Spectrophotometric Method]
}

\author{
Maghfira Jurwita, M. Nasir, Abdul Gani* \\ Jurusan Pendidikan Kimia FKIP Universitas Syiah Kuala, Banda Aceh, Indonesia \\ *Coresponding author : abdulgani051266@gmail.com (hp: +628121815214)
}

\begin{abstract}
An analysis of vitamin C levels of garlic and black garlic was done by UV-Vis spectrophotometric method. Garlic and black garlic contain a variety of nutrients and vitamins. Single and plural garlic is widely used as a medicine, besides garlic is currently also popular with garlic which is processed at temperatures between 60$80^{\circ} \mathrm{C}$ with an environmental humidity of around $70-90 \%$ for $10-40$ days. One of the vitamins contained in garlic includes vitamin $C$ which acts as an antioxidant and is effective in dealing with free radicals. Vitamin $C$ analysis was performed by the spectrophotometric method on the maximum wavelength is $250 \mathrm{~nm}$ with an absorbance value of 3.994. Results of analysis of vitamin C levels single garlic by $0.28 \%$ content of plural garlic by $0.27 \%$. Vitamin C levels of single black garlic $0.29 \%$ (10 days), $0.31 \%$ (20 days), and $0.32 \%$ (30 days), plural black garlic Vitamin C levels $0.28 \%$ (10 days), $0.29 \%$ ( 20 days) and $0.31 \%$ (30 days).Based on ANOVA test results obtained there are differences in levels of vitamin $\mathrm{C}$ in single black garlic over several variations of time (days)and there are differences in levels of vitamin $\mathrm{C}$ in plural black garlic over several variations of time (days) because of Fcount $\geq$ Ftable.The coefficient of variation (KV) value is needed to test the level of accuracy of the analysis results. KV value in single garlic is $0.68 \%$ and plural garlic is $1.24 \%$. KV value of single black garlic $0.3 \%$ (10 days), $0.25 \%$ (20 days), and $0.7 \%$ ( 30 days), $\mathrm{KV}$ of black garlic $0.55 \%$ (10 days), $0.61 \%$ ( 20 days), and $0.43 \%$ (30 days).
\end{abstract}

Keywords: Single garlic, garlic plural, black garlic, fermentation, vitamin C levels

ABSTRAK. Telah dilakukan penelitian analisis kadar vitamin C bawang putih dan hitam dengan metode spektrofotometri UV-tampak. Bawang putih dan hitam mengandung berbagai macam zat gizi dan vitamin. Bawang putih tunggal dan jamak banyak digunakan sebagai obat, selain bawang putih saat ini juga popular dengan bawang hitam yang diproses pada suhu antara $60-80^{\circ} \mathrm{C}$ dengan kelembaban lingkungan sekitar $70-90 \%$ selama $10-40$ hari. Salah satu vitamin yang terkandung dalam bawang putih diantaranya vitamin $\mathrm{C}$ yang berperan sebagai antioksidan dan efektif mengatasi radikal bebas. Analisis vitamin $\mathrm{C}$ dilakukan dengan metode spektrofotometri pada panjang gelombang maksimum $250 \mathrm{~nm}$ dengan nilai absorbansi 3,994. Hasil analisis kadar vitamin $\mathrm{C}$ bawang putih tunggal sebesar 0,28\% kadar bawang putih jamak sebesar 0,27\%. Kadar vitamin C bawang hitam tunggal 0,29\% (10 hari), 0,31\% (20 hari), dan 0,32\% (30 hari), bawang hitam jamak Kadar vitamin C 0,28\% (10 hari), 0,29\% (20 hari), dan $0,31 \%$ (30 hari). Berdasarkan hasil uji anova diperoleh terdapat perbedaan kadar vitamin $\mathrm{C}$ pada bawang hitam tunggal terhadap beberapa variasi waktu (hari) dan terdapat perbedaan kadar vitamin $\mathrm{C}$ pada bawang hitam jamak

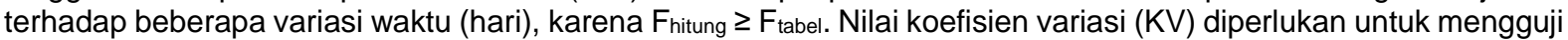
tingkat ketelitian hasil analisis. Nilai KV pada bawang putih tunggal sebesar 0,68\% dan bawang putih jamak 1,24\%. Nilai KV bawang hitam tunggal 0,3\% (10 hari), 0,25\% (20 hari), dan 0,7\% (30 hari), KV bawang hitam $0,55 \%$ (10 hari), 0,61\% (20 hari), dan 0,43\% (30 hari).

Kata Kunci: Bawang putih tunggal, bawang putih jamak, bawang hitam, fermentasi, kadar vitamin $C$

Riwayat artikel: Diterima 18 September 2020, Disetujui 20 Desember 2020

Cara sitasi: Jurwita, M., Nasir, M., dan Gani, A. (2020). Analisis Kadar Vitamin C Bawang Putih dan Hitam dengan Metode Spektrofotometri UV-Vis. KOVALEN: Jurnal Riset Kimia, 6(3): 252-261.

DOI: https://doi.org/10.22487/kovalen.2020.v6.i3.15289 


\section{LATAR BELAKANG}

Tanaman obat dipercaya masyarakat mempunyai khasiat dan telah digunakan secara turun temurun berdasarkan pengalaman. Setiap bagian tanaman dapat dimanfaatkan sebagai obat seperti akar, batang dan daun. Diantara berbagai macam tanaman obat yang tersebar di alam, bawang putih merupakan tanaman yang memiliki banyak manfaat. Bawang putih juga merupakan obat beberapa penyakit seperti infeksi pernafasan dan untuk meningkatkan vitalitas tubuh. Bawang putih dapat mengatasi influenza, letih, lelah, dan sulit tidur, karena bawang putih efektif dalam mengganti kekurangan vitamin C (Untari, 2010).

Bawang putih (Allium sativum Linn.) terdiri dari beberapa jenis, salah satu diantaranya adalah bawang lanang. Bawang lanang (umbi tunggal) merupakan varietas yang terbentuk tidak sengaja karena lingkungan penanaman yang tidak cocok. Bawang lanang pertama kali ditemukan di daerah Sarangan, Magetan, Jawa Timur. Umbi dari tanaman ini hanya berisi satu umbi utuh yang kecil. Hal ini disebabkan karena gagalnya pembentukan tunas utama dan menekan pembentukan tunas-tunas bakal siung, daun yang biasanya membungkus siungsiung hanya mampu membungkus umbi utuh, sehingga kulit umbi utuh lebih tebal daripada kulit luar umbi yang bersiung (Syamsiah \& Tajudin, 2003). Produk olahan yang berasal dari bawang putih di beberapa negara seperti Cina dan Korea Selatan sudah banyak, salah satunya bawang hitam.

Bawang putih tunggal dan jamak dapat diolah dengan cara dipanaskan pada suhu 65 $80^{\circ} \mathrm{C}$ dengan kelembapan $70-80 \%$ dari suhu kamar selama satu bulan dan menghasilkan bawang hitam atau black garlic (Wang et al., 2010). Proses pemanasan memberikan pengaruh terhadap meningkatnya vitamin larut air (termasuk vitamin $C$ ) hingga 1,15 sampai 1,92 kali bawang putih biasa. Black garlic (Allium sativum Linn.) memiliki warna hitam, ringan karena kadar airnya berkurang dan mempunyai aroma serta rasa yang tidak terlalu menyengat seperti bawang putih.

Bawang putih dan hitam tunggal dan jamak merupakan salah satu tanaman yang mengandung berbagai macam vitamin. Salah satu vitamin yang terdapat dibawang putih dan bawang hitam yaitu vitamin C. Vitamin C berperan sebagai antioksidan dan efektif mengatasi radikal bebas yang merusak sel atau jaringan. Beberapa vitamin yang terdapat dalam 100 gram bawang putih diantaranya adalah vitamin C, Tiamin, Riboflavin, Niacin, B6, Folat, B12, B16, A, E, D, dan K (Moulia et al., 2018). Ada beberapa metode yang dikembangkan untuk menentukan kadar vitamin $\mathrm{C}$, salah satunya adalah metode spektrofotometri.

Spektrofotometri dapat digunakan untuk informasi baik secara analisis kualitatif maupun analisis kuantitatif. Metode ini memiliki keuntungan, yakni lebih cepat serta menggunakan pelarut yang sedikit. Metode spektrofotometri juga memberikan cara sederhana untuk menetapkan kuantitas zat yang sangat kecil serta angka yang terbaca langsung tercatat oleh detektor.

Beberapa penelitian yang telah dilakukan dalam penentuan kadar vitamin $\mathrm{C}$ dengan menggunakan metode spektrofotometri, diantaranya adalah kadar vitamin $\mathrm{C}$ yang terkandung didalam umbi bawang hutan (Eleutherine bulbosa (Mill) Urb) dengan larutan etanol $96 \%$ adalah $31,678 \mathrm{mg} / 100 \mathrm{~g}$ (Karmila et al., 2018). Kadar vitamin $C$ yang terkandung didalam umbi kimpul sebesar 2,61 mg/100 g (Yashika et al., 2018). Kadar vitamin C yang 
terkandung didalam ubi kayu adalah 360 $\mathrm{mg} / 100 \mathrm{~g}$ dan pada ubi jalar sebesar $230 \mathrm{mg} / 100 \mathrm{~g}$ (Simanjuntak, 2006). Kadar vitamin $\mathrm{C}$ yang terkandung dalam bawang putih adalah 27,45 mg/100 g (Karmila et al., 2018). Beradasarkan uraian latar belakang maka peneliti melakukan tentang analisis kadar vitamin $\mathrm{C}$ bawang putih dan hitam dan dengan metode spektrofotometri.

\section{METODE PENELITIAN}

\section{Bahan dan Peralatan}

Bahan-bahan yang digunakan pada penelitian ini yaitu bawang putih jamak, bawang putih tunggal, betadin, kristal asam askorbat $\left(\mathrm{C}_{6} \mathrm{H}_{8} \mathrm{O}_{6}\right)$, aluminium foil, kertas saring, dan aquades $\left(\mathrm{H}_{2} \mathrm{O}\right)$.

Alat-alat yang digunakan pada penelitian ini yaitu timbangan analitik, corong, spatula, labu ukur, gelas ukur, cawan penguap, Erlenmeyer, gelas kimia, batang pengaduk, pipet tetes, blender, rice cooker, dan seperangkat alat spektrofotometri UV-vis.

\section{Prosedur Penelitian}

\section{Pembuatan bawang hitam}

Bawang putih sebanyak 250 gram dipilih yang berukuran besar, tidak busuk, dan masih utuh menyatu dengan siung yang lain bukan yang pecah. Bawang putih dibiarkan tanpa dikupas dan dibiarkan dalam keadaan kering dan tidak lembab. Bawang putih dimasukan kedalam rice cooker dan ditata tidak saling tindih untuk mencegah kerusakan bentuk bawang hitam. Rice cooker ditutup dan diatur dalam mode keep warm dan dibiarkan selama 12 hari. Setelah 12 hari, bawang putih dikeluarkan dan dipilih bawang hitam yang memiliki kulit siung tidak gosong dan bawang putih didalamnya berwarna hitam dan kisut sehingga didapatkan bawang hitam (Aini \& Shovitri, 2018).
Tabel 1. Variasi jenis bawang putih terhadap lama waktu

\begin{tabular}{ccc}
\hline No & Sampel & $\begin{array}{c}\text { Lama variasi waktu } \\
\text { (Hari) }\end{array}$ \\
\hline & & 0 \\
1 & Bawang putih & 10 \\
& tunggal & 20 \\
& & 30 \\
& & \\
2 & Bawang putih & 10 \\
& jamak & 20 \\
& & 30 \\
\hline
\end{tabular}

\section{Identifikasi vitamin C}

Larutan sampel sebanyak $2 \mathrm{~mL}$ ditambahkan tetes demi tetes betadine, warna betadin akan berkurang atau hilang \pm 3 menit (Arel et al., 2017).

\section{Pembuatan larutan induk vitamin C 1000 ppm}

Asam askorbat ditimbang sebanyak 100 mg kemudian dimasukkan ke dalam labu ukur $100 \mathrm{~mL}$ dan dilarutkan dengan aquades sampai tanda batas (Arel et al., 2017).

\section{Penentuan panjang gelombang maksimum larutan vitamin $C$}

Larutan vitamin C 1000 ppm sebanyak 10 $\mathrm{ml}$ dimasukkan kedalam labu ukur $100 \mathrm{~mL}$ (konsentrasi 100 ppm). Lalu ditambahkan aquades sampai tanda batas dan dihomogenkan. Diukur serapan maksimum pada panjang gelombang $200-400 \mathrm{~nm}$ dengan menggunakan blanko aquades.

\section{Pembuatan kurva kalibrasi}

Larutan vitamin C 100 ppm dimasukkan kedalam labu ukur $50 \mathrm{ml}$ masing-masing sebanyak 3; 3,5; 4; dan 4,5 mL (12, 14, 16, dan 18 ppm). Selanjutnya ditambahkan aquades hingga tanda batas lalu dihomogenkan, kemudian diukur serapannya pada panjang gelombang maksimum (250 nm) (Wardani, 2012). 


\section{Penentuan kadar bawang hitam}

Bawang hitam yang telah dihaluskan dimasukkan ke dalam labu ukur $100 \mathrm{~mL}$ lalu ditambahkan aquades sampai tanda batas kemudian dihomogenkan, dan disaring dengan kertas saring. Diambil sebanyak $10 \mathrm{~mL}$ filtrat, dimasukkan ke dalam labu ukur $100 \mathrm{~mL}$ dan ditambahkan aquades hingga tanda batas. Selanjutnya, diukur serapannya pada panjang gelombang maksimum dan dilakukan pengulangan sebanyak 3 kali.

\section{Perhitungan kadar vitamin C}

Perhitungan persentase kadar vitamin $\mathrm{C}$ bawang putih tunggal dan jamak mengacu pada hasil penelitian Azizah (2017) dengan persamaan sebagai berikut:

$$
A(\%)=\frac{C \times V}{Z} \times F p
$$

Dimana:

$\mathrm{A}=$ Persentase sampel terukur (\%)

$\mathrm{Z}$ = Berat sampel (mg)

$\mathrm{C}=$ Konsentrasi yang diperoleh $(\mathrm{mg} / \mathrm{L})$

$\mathrm{Fp}=$ Faktor pengenceran

$\mathrm{V}=$ Volume sampel $(\mathrm{mL})$

\section{Teknik analisis data}

Analisis data kadar vitamin $\mathrm{C}$ bawang putih dan hitam dilakukan dengan uji Anova yang menggunakan aplikasi SPSS versi 18 . Signifikansi dari masing-masing niai ditentukan dengan taraf signifikansi 0,01.

\section{HASIL DAN PEMBAHASAN}

\section{Hasil Identifikasi Vitamin C}

Vitamin $\mathrm{C}$ pada bawang putih tunggal dan jamak dapat diidentifikasi dengan menggunakan betadin sebagai indikator dan menggunakan aquades sebagai pelarut. Aquades digunakan sebagai pelarut karena dapat mengurangi resiko keberadaan zat pengotor. Hal ini sesuai dengan Suhaera et al. (2019) yang menyatakan vitamin $\mathrm{C}$ merupakan vitamin yang larut dalam air, maka pelarut yang digunakan adalah aquades dengan tujuan untuk mengurangi resiko keberadaan zat pengotor. Sampel yang telah diuji dengan betadin dan menunjukkan hasil positif pada bawang putih tunggal dan jamak ditandai dengan menghilangnya warna betadin pada sampel. Hasil identifikasi vitamin $\mathrm{C}$ dengan betadin dapat dilihat pada Tabel 1.

Tabel 1. Hasil identifikasi vitamin $\mathrm{C}$ bawang putih tunggal dan jamak

\begin{tabular}{ccccc}
\hline $\begin{array}{c}\text { Bawang } \\
\text { Putih }\end{array}$ & $\begin{array}{c}\text { Identifikasi } \\
\text { vitamin C }\end{array}$ & Warna Betadin & Perubahan Warna Betadin & Vitamin C \\
\hline Tunggal & betadin & $\begin{array}{c}\text { Coklat } \\
\text { Kemerahan }\end{array}$ & $\begin{array}{c}\text { hilang selama 3 menit (larutan } \\
\text { tidak berwarna) }\end{array}$ & $\begin{array}{c}\text { Positif } \\
(+)\end{array}$ \\
Jamak & betadin & $\begin{array}{c}\text { Coklat } \\
\text { Kemerahan }\end{array}$ & $\begin{array}{c}\text { hilang selama 3 menit (larutan } \\
\text { tidak berwarna) }\end{array}$ & $\begin{array}{c}\text { Positif } \\
(+)\end{array}$ \\
\hline
\end{tabular}

Hasil identifikasi berdasarkan data dari Tabel 1 diperoleh bahwa sampel bawang putih tunggal dan jamak positif terdapat vitamin $\mathrm{C}$. Hal ini dapat dilihat dari warna betadin yang berwarna coklat kemerahan ketika diteteskan kedalam ekstrak bawang putih tunggal dan jamak dalam waktu 3 menit warna betadin menghilang, sehingga dengan menghilangnya warna betadin didalam ekstrak tersebut menandakan positif vitamin C pada sampel bawang putih tunggal dan jamak. Hal ini sesuai dengan Arel et al. (2017) yang menyatakan sampel yang ditambahkan tetes demi tetes betadin, warna betadin akan berkurang atau 
hilang \pm 3 menit. Warna sampel sebelum diteteskan betadin yaitu tidak berwarna, dan menghasilkan warna yang sama ketika diteteskan betadin. Hasil sebelum dan sesudah diteteskan betadin dapat dilihat pada Gambar 1 dan Gambar 2.

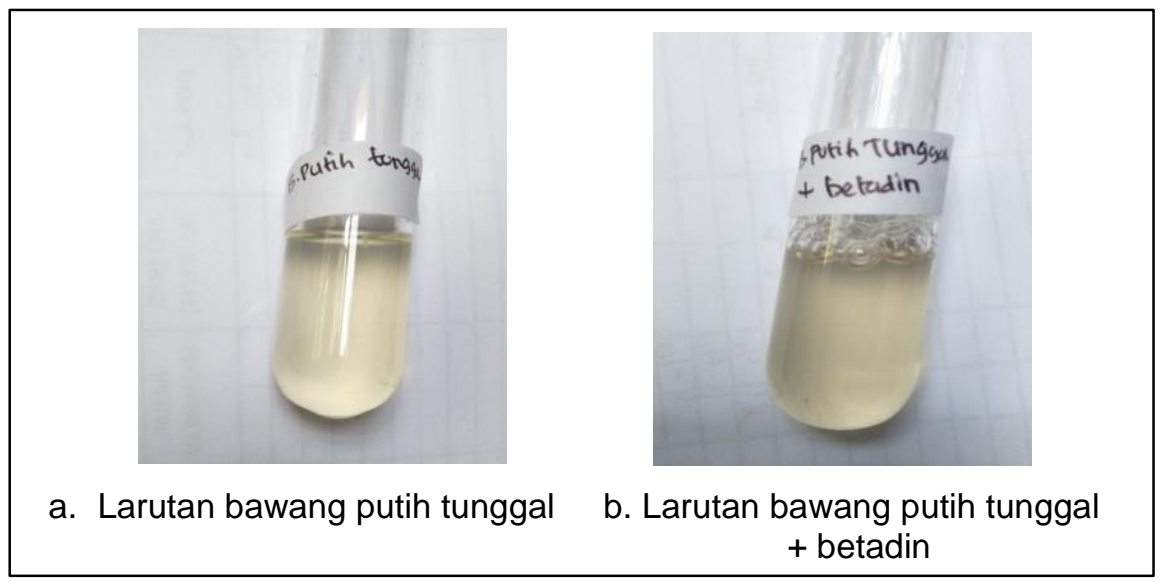

Gambar 1. Hasil identifikasi bawang putih tunggal

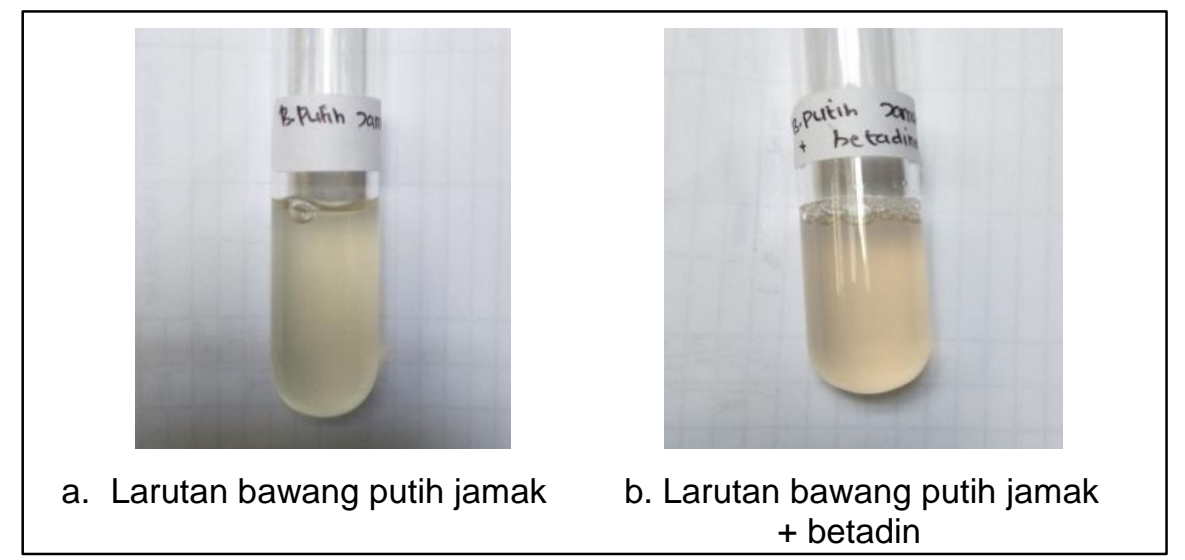

Gambar 2. Hasil identifikasi bawang putih jamak

\section{Panjang Gelombang Maksimum Vitamin C}

Penentuan panjang gelombang maksimum dapat diketahui dengan mengukur nilai absorbansi larutan standar asam askorbat 100 ppm pada rentang panjang gelombang 200-300 $\mathrm{nm}$ dengan menggunakan spektrofotometri UVvis. Hasil pengukuran absorbansi asam askorbat 100 ppm ditunjukkan pada Tabel 2.

Hasil yang diperoleh berdasarkan pengukuran dari spektrofotometri UV-vis, panjang gelombang maksimum larutan standar asam askorbat yaitu $250 \mathrm{~nm}$ dengan nilai absorbansi sebesar 3,994.
Tabel 2. Pengukuran absorbansi asam askorbat $100 \mathrm{ppm}$

\begin{tabular}{cc}
\hline $\begin{array}{c}\text { Panjang } \\
\text { gelombang }(\mathrm{nm})\end{array}$ & Absorbansi \\
\hline 230 & 2,55 \\
235 & 3,166 \\
240 & 3,587 \\
245 & 3,851 \\
250 & 3,994 \\
255 & 3,956 \\
260 & 3,862 \\
265 & 3,736 \\
270 & 3,681 \\
275 & 3,635 \\
280 & 3,615
\end{tabular}




\section{Kurva Kalibrasi Vitamin C}

Pembuatan kurva kalibrasi vitamin $\mathrm{C}$ untuk mengetahui daerah rentang linearitas larutan standar vitamin C. Penentuan kurva kalibrasi vitamin C menggunakan absorbansi yang diperoleh dari hasil pengukuran dengan menggunakan variasi konsentrasi yang dibuat. Larutan induk 100 ppm dibuat dengan sederetan kosentrasi, diantaranya 12, 14, 16, dan 18 ppm.

Tabel 3. Absorbansi asam askorbat pada panjang gelombang $250 \mathrm{~nm}$

\begin{tabular}{cc}
\hline Konsentrasi (ppm) & Absorbansi \\
\hline 12 & 0,293 \\
14 & 0,328 \\
16 & 0,559 \\
18 & 0,758 \\
\hline
\end{tabular}

Absorbansi yang diperoleh diukur menggunakan spektrofotometri UV-vis pada panjang gelombang maksimum yang diperoleh pada larutan induk vitamin C. Panjang gelombang maksimum yang digunakan pada penelitian ini yaitu $250 \mathrm{~nm}$. Hasil pengukuran absorbansi vitamin $\mathrm{C}$ dapat dilihat pada Tabel 3 . Absorbansi yang diperoleh kemudian dibuat dalam bentuk kurva.

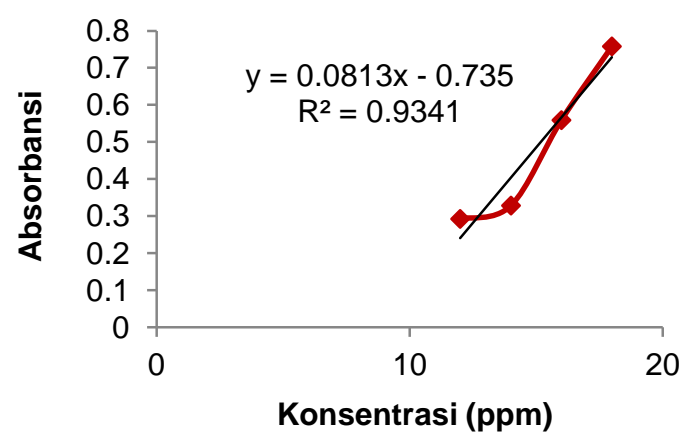

Gambar 4. Kurva kalibrasi asam askorbat

Kurva kalibrasi asam askorbat menunjukkan bahwa meningkatnya nilai absorbansi yang terukur dipengaruhi oleh peningkatan konsentrasi vitamin C. Artinya semakin besar konsentrasi larutan standar vitamin $\mathrm{C}$, maka semakin besar absorbansi yang dihasilkan. Fadliya et al. (2018) menyatakan peningkatan konsentrasi vitamin $\mathrm{C}$ akan mengakibatkan peningkatan nilai absorbansi yang terbaca pada spektrofotometri UV-vis secara linear. Hal ini sesuai dengan hukum Lambert-Beer yang menyatakan bahwa konsentrasi suatu sampel berbanding lurus dengan nilai absorbansi.

Berdasarkan nilai-nilai absorbansi larutan standar tersebut, maka diperoleh persamaan regresi linear dari kurva kalibrasi adalah $\mathrm{y}=$ $0,0813 x-0,735$ dengan nilai koefisien korelasi (r) sebesar 0,9341 yang menunjukkan linearitas dari persamaan. Jika nilai $r=+$ (positif), maka hubungan konsentrasi dan absorbansi berbanding lurus, artinya nilai $r$ yang didapat sudah sesuai dengan hukum Lambert-Beer (Primadiamanti et al., 2019). Hal ini sesuai dengan penelitian Chandra et al. (2019) yang menyatakan koefisien korelasi ini menunjukkan hasil linear, karena memenuhi persyaratan dimana nilai $(r)$ berada pada rentang $0,9 \leq r \leq 1$. Maka kurva kalibrasi ini sudah cukup baik, dan persamaan garis regresi dapat digunakan untuk perhitungan kadar vitamin $\mathrm{C}$ didalam sampel.

\section{Kadar Vitamin C Bawang Putih dan Hitam}

Analisis kadar vitamin $\mathrm{C}$ pada bawang putih tunggal dan jamak ditentukan menggunakan spektrofotometri UV-vis. Nilai absorbansi yang diperoleh dimasukkan dalam persamaan kurva kalibrasi dengan cara mensubstitusikan nilai absorbansi larutan sampel terhadap persamaan (y). Penentuan kadar vitamin C pada bawang putih tunggal dan jamak dilakukan sebanyak 3 kali pengulangan, dengan maksud mengetahui berapa persen kadar vitamin $\mathrm{C}$ pada bawang putih tunggal dan jamak. Nilai absorbansi yang diperoleh dimasukkan dalam persamaan kurva 
kalibrasi analisis kadar vitamin $\mathrm{C}$ pada bawang putih tunggal dan jamak dengan menggunakan persamaan 1 sehingga berdasarkan perhitungan tersebut diperoleh kadar vitamin $\mathrm{C}$ pada bawang putih tunggal dan jamak. Hasil kadar vitamin $\mathrm{C}$ pada bawang putih tunggal dan jamak dapat dilihat pada Tabel 4 dan Tabel 5.

Tabel 4. Kadar vitamin $C$ bawang hitam tunggal berdasarkan variasi waktu (hari)

\begin{tabular}{ccc}
\hline $\begin{array}{c}\text { Variasi } \\
\text { Waktu (Hari) }\end{array}$ & $\begin{array}{c}\text { Konsentrasi } \\
(\mathrm{mg} / \mathrm{mL})\end{array}$ & $\begin{array}{c}\text { Kadar } \\
\text { vitamin C } \\
(\%)\end{array}$ \\
\hline 0 & 0,0172 & 0,28 \\
10 & 0,0178 & 0,29 \\
20 & 0,0187 & 0,31 \\
30 & 0,0194 & 0,32 \\
\hline
\end{tabular}

Hasil kadar pada tabel diatas menunjukkan semakin lama variasi waktu pada bawang hitam tunggal dan jamak, maka semakin tinggi pula kadar vitamin $\mathrm{C}$ pada bawang hitam tunggal dan jamak. Kadar vitamin C pada bawang putih tunggal sebesar $0,28 \%$ ( 0 hari) dan jamak sebesar $0,27 \%$ ( 0 hari). Kadar vitamin C pada bawang hitam tunggal sebesar $0,29 \%$ (10 hari), 0,31\% (20 hari), dan $0,32 \%$ (30 hari), sedangkan pada bawang hitam jamak sebesar 0,28\% (10 hari), 0,29\% (20 hari), dan 0,31\% (30 hari). Hasil analisis pada sampel bawang putih dan hitam tunggal dan jamak terdapat perbedaan kadar vitamin C antara kedua bawang tersebut, ini dapat disebabkan oleh perbedaan varietas. Perbedaan varietas pada bawang putih dan hitam tunggal dan jamak ternyata berpengaruh terhadap kadar vitamin $\mathrm{C}$ yang terkandung. $\mathrm{Hal}$ ini sesuai dengan hasil penelitian (Risnayanti et al., 2015) yang menyatakan adanya perbedaan kandungan zat gizi disebabkan karena perbedaan varietas dan pengaruh tempat tumbuh. Rahman et al. (2015) juga menyatakan kadar vitamin $\mathrm{C}$ sangat dipengaruhi oleh varietas, lingkungan, tempat tunbuh, dan lainlain.

Tabel 5. Kadar vitamin C bawang hitam jamak berdasarkan variasi waktu (hari)

\begin{tabular}{ccc}
\hline $\begin{array}{c}\text { Variasi Waktu } \\
\text { (Hari) }\end{array}$ & $\begin{array}{c}\text { Konsentrasi } \\
(\mathrm{mg} / \mathrm{mL})\end{array}$ & $\begin{array}{c}\text { Kadar } \\
\text { Vitamin C } \\
(\%)\end{array}$ \\
\hline 0 & 0,0163 & 0,27 \\
10 & 0,0169 & 0,28 \\
20 & 0,0179 & 0,29 \\
30 & 0,0189 & 0,31 \\
\hline
\end{tabular}

\section{Hasil Uji Presisi}

Uji presisi adalah ukuran yang menunjukkan kesesuaian antara hasil uji individual dan rata-rata. Untuk menetapkan presisi dilakukan perhitungan simpangan baku relatif (RSD) atau koefisien variasi (KV). Berdasarkan data hasil pengukuran kadar vitamin C pada bawang putih tunggal dan bawang putih jamak, diperoleh nilai KV yang terdapat pada Tabel 6 dan Tabel 7.

Tabel 6. Hasil koefisien variasi pada bawang putih tunggal berdasarkan variasi waktu

\begin{tabular}{cccc}
\hline $\begin{array}{c}\text { Variasi } \\
\begin{array}{c}\text { Waktu } \\
\text { (hari) }\end{array}\end{array}$ & $\begin{array}{c}\text { Konsentrasi } \\
(\mathrm{mg} / \mathrm{mL})\end{array}$ & $\mathrm{SD}$ & $\mathrm{KV}(\%)$ \\
\hline 0 & 0,0172 & 0,004582 & 0,68 \\
10 & 0,0178 & 0,003 & 0,3 \\
20 & 0,0187 & 0,002 & 0,25 \\
30 & 0,0194 & 0,00667 & 0,7 \\
\hline
\end{tabular}

Nilai KV yang diperoleh berdasarkan tabel diatas pada bawang putih tunggal sebesar 0,68 \% (0 hari), 0,3\% (10 hari), 0,25\% (20 hari), dan $0,7 \%$ (30 hari) (Tabel 6), sedangkan pada bawang putih jamak sebesar sebesar 1,24 \% (0 hari), 0,55\% (10 hari), 0,61\% (20 hari), dan 0,43 $\%$ (30 hari) (Tabel 7). Nilai KV menunjukkan tingkat ketelitian dari pengukuran. Ketelitian 
adalah ukuran yang menunjukkan kesesuaian antara hasil uji individu dan rata-rata jika prosedur dilakukan berulang-ulang (Arel et al., 2017).

Tabel 7. Hasil koefisien variasi pada bawang putih jamak berdasarkan variasi waktu

\begin{tabular}{cccc}
\hline $\begin{array}{c}\text { Variasi } \\
\text { Waktu } \\
\text { (hari) }\end{array}$ & $\begin{array}{c}\text { Konsentrasi } \\
(\mathrm{mg} / \mathrm{mL})\end{array}$ & SD & KV (\%) \\
\hline 0 & 0,0163 & 0,0073 & 1,24 \\
10 & 0,0169 & 0,00360 & 0,55 \\
20 & 0,0179 & 0,00447 & 0,61 \\
30 & 0,0189 & 0,00346 & 0,43 \\
\hline
\end{tabular}

Keterangan:

$\mathrm{SD}=$ Standar deviasi

$\mathrm{KV}=$ Koefisien variasi

Hasil yang diperoleh menunjukkan bahwa metode uji yang digunakan pada penentuan kadar vitamin $\mathrm{C}$ pada bawang putih tunggal dan bawang putih jamak menggunakan spektrofotometri UV-Vis telah memenuhi persyaratan nilai persentase $\mathrm{KV}$ yang diterima, yaitu lebih kecil dari $2 \%$. Nilai presisi dapat ditentukan dengan membandingkankan RSD atau KV dengan syarat keberterimaan. Kriteria seksama diberikan jika nilai $\% \mathrm{KV} \leq 2 \%$ (Harmita, 2004).

\section{Hasil Analisis Data}

Uji Anova pada sampel bawang putih dan hitam tunggal dan jamak berdasarkan variasi waktu dilakukan pada taraf kepercayaan 99\% ( $\alpha$ $=0,01)$ untuk penelitian laboratorium. Uji Anova dilakukan untuk mengetahui apakah terdapat perbedaan signifikan pada perlakuan. Analisis jenis rancangan percobaan yang digunakan adalah rancangan acak lengkap (RAL). Uji anova kadar vitamin $\mathrm{C}$ jika terdapat perbedaan ditandai dengan $F_{\text {hitung }} \geq F_{\text {tabel. }}$.

Hasil Anova kadar vitamin C pada bawang hitam tunggal terhadap variasi waktu yaitu $F_{\text {hitung }} 898,489 \geq F_{\text {tabel }} 7,59$, sedangkan pada perlakuan kadar vitamin $\mathrm{C}$ pada bawang hitam jamak terhadap variasi waktu yaitu $F_{\text {hitung }}$ $922,562 \geq F_{\text {tabel }} 7,59$. Maka tolak $\mathrm{H}_{0}$, artinya terdapat perbedaan signifikan kadar vitamin $\mathrm{C}$ bawang hitam tunggal dan jamak terhadap variasi waktu.

Kadar vitamin C pada bawang hitam tunggal dan jamak terdapat perbedaan disebabkan berbeda varietas dan variasi waktu. Hal ini sesuai dengan pendapat Satria \& Tarigan (2017) yang menyatakan kadar vitamin C dapat berbeda-beda dikarenakan varietas, waktu, suhu, lama penyimpanan, dan lain-lain.

\section{KESIMPULAN}

Kadar vitamin $\mathrm{C}$ pada bawang putih tunggal 0 hari sebesar $0,28 \%, 10$ hari $(0,30 \%), 20$ hari $(0,31 \%)$, dan 30 hari $(0,32 \%)$, sedangkan pada bawang putih jamak 0 hari sebesar 0,27\%, 10 hari $(0,28 \%), 20$ hari $(0,29 \%)$, dan 30 hari $(0,31 \%)$. Terdapat perbedaan signifikan antara kadar vitamin C pada bawang putih tunggal antara beberapa variasi waktu dan terdapat perbedaan signifikan antara kadar vitamin C pada bawang putih jamak antara beberapa variasi waktu.

\section{UCAPAN TERIMAKASIH}

Penulis mengucapkan terimakasih kepada Universitas Syiah Kuala untuk dukungan fasilitas pada penelitian ini dan kepada laboran Pendidikan Kimia untuk pelayanan dalam penelitian ini.

\section{DAFTAR PUSTAKA}

Aini, S. Q., \& Shovitri, M. (2018). Studi Awal Pemanfaatan Bawang Putih yang dihitamkan sebagai Antibakteri. Jurnal Sains dan Seni ITS, 7(1): 9-12-12. https://doi.org/10.12962/j23373520.v7i1.29 848 
Arel, A., Martinus, B. A., \& Ningrum, S. A. (2017). Penetapan Kadar Vitamin C Pada Buah Naga Merah (Hylocereus costaricensis (F.A.C. Weber) Britton \& Rose) Dengan Metode Spektrofotometri UV-Visibel. SCIENTIA : Jurnal Farmasi dan Kesehatan, $\quad 7(1)$ : 1-5. https://doi.org/10.36434/scientia.v7i1.96

Azizah, I. (2017). Penentuan Kadar Vitamin C dalam Buah Jambu Biji (Psidium guajava L.) dengan Pereaksi 2,6-Diklorofenol Indofenol secara Spektrofotometri Sinar Tampak [Skripsi]. Universitas Islam Negeri Sunan Kalijaga, Yogyakarta.

Chandra, B., Zulharmita, Z., \& Putri, W. D. (2019). Penetapan Kadar Vitamin C Dan B1 Pada Buah Naga Merah (Hylocereus Lemairel (Hook.) Britton \& Rose) Dengan Metode Spektrofotometri Uv-Vis. Jurnal Farmasi Higea, 11(1): 62-74.

Fadliya, F., Supriadi, S., \& Diah, A. W. M. (2018). Analisis Vitamin C dan Protein pada Biji Buah Labu Siam (Sechium edule). Jurnal Akademika Kimia, 7(1): 6-10.

Harmita, H. (2004). Petunjuk Pelaksanaan Validasi Metode Dan Cara Perhitungannya. Pharmaceutical Sciences and Research (PSR), 1(3): 117-135. https://doi.org/10.7454/psr.v1i3.3375

Karmila, K., Jura, M. R., \& Tiwow, V. M. A. (2018). Penentuan Kadar Flavonoid dan Vitamin C dalam Umbi Bawang Hutan (Eleutherine bulbosa (Mill) Urb) yang Berasal dari Desa Matantimali Kabupaten Sigi. Jurnal Akademika Kimia, 7(2): 66-6969.

Moulia, M. N., Syarief, R., Iriani, E., Kusumaningrum, H., \& Suyatma, N. (2018). Antimikroba Ekstrak Bawang Putih. JURNAL PANGAN, 27(1): 55-66. https://doi.org/10.33964/jp.v27i1.399

Primadiamanti, A., Feladita, N., \& Juliana, R. (2019). Penetapan Kadar Hidrokuinon Pada Krim Pemutih Herbal Yang Dijual Dilorong King Pasar Tengah Kota Bandar Lampung Menggunakan Metode Spektrofotometri UV-Vis. Jurnal Analis Farmasi, 4(1): 10-16.
Rahman, N., Ofika, M., \& Said, I. (2015). Analisis Kadar Vitamin C Mangga Gadung (Mangifera sp) Dan Mangga Golek (Mangifera indica L) Berdasarkan Tingkat Kematangan Dengan Menggunakan Metode lodimetri. Jurnal Akademika Kimia, 4(1): 33-37.

Risnayanti, R., Sabang, S. M., \& Ratman, R. (2015). Analisis Perbedaan Kadar Vitamin C Buah Naga Merah (Hylocereus polyrhizus) Dan Buah Naga Putih (Hylocereus undatus) Yang Tumbuh Di Desa Kolono Kabupaten Morowali Provinsi Sulawesi Tengah. Jurnal Akademika Kimia, 4(2): 91-96.

Satria, D., \& Tarigan, R. E. (2017). Analisis Kandungan Vitamin C Pada Buah Stroberi (Fragaria $x$ ananassa Duschesne) Secara Spektrofotometri Ultraviolet (UV). JURNAL FARMANESIA, 4(1): 31-40.

Simanjuntak, D. (2006). Pemanfaatan komoditas non beras dalam diversifikasi pangan sumber kalori. Jurnal Penelitian Bidang IImu Pertanian, 4(1): 45-54.

Suhaera, S., Sammulia, S. F., \& Islamiah, H. (2019). Analisis Kadar Vitamin C pada Buah Naga Merah (Hylocereus lemairei (Hook.) Britton \& Rose) dan Buah Naga Putih (Hylocereus undatus (Haw.) Britton \& Rose) di Kepulauan Riau menggunakan Spektrofotometri Ultraviolet. PHARMACY: Jurnal Farmasi Indonesia (Pharmaceutical Journal of Indonesia), 16(1): 146-152. https://doi.org/10.30595/pharmacy.v16i1.4 579

Syamsiah, I., \& Tajudin. (2003). Khasiat dan Manfaat Bawang Putih. Agromedia Pustaka, Jakarta.

Untari, I. (2010). Bawang Putih Sebagai Obat Paling Mujarab Bagi Kesehatan. Gaster, 7(1): 547-554.

Wang, D., Feng, Y., Liu, J., Yan, J., Wang, M., Sasaki, J., \& Lu, C. (2010). Black garlic (Allium sativum) extracts enhance the immune system. Medicinal and Aromatic Plant Science and Biotechnology, 4(1): 3740.

Wardani, L. (2012). Validasi Metode Analisis dan Penentuan Kadar Vitamin C pada 
Minuman Buah Kemasan dengan

Spektrofotometri UV-vis. [Skripsi].

Universitas Indonesia, Depok.

Yashika, P. P., Ina, P. T., \& Putra, N. (2018).

Pengaruh Perbandingan Umbi Kimpul (Xanthosoma sagittifolium) Dengan Daun

Kelor (Moringa oleifera) Terhadap

Karakteristik Keripik Simulasi. Media IImiah

Teknologi Pangan, 5(1): 1-10. 